\section{Informationists in a Small University Library}

\section{Elizabeth A. Thomas, Nora Bird, and Richard J. Moniz Jr., Guest Columnists}

\author{
Correspondence concerning this column should be \\ addressed to: Diane Zabel, Schreyer Business Library, \\ The Pennsylvania State University, 309 Paterno Library, \\ University Park, PA 16802; e-mail:dxz2@psu.edu.
}

Elizabeth A. Thomas is a recent MLIS graduate. Nora Bird is Assistant Professor, University of North Carolina at Greensboro. Richard J. Moniz Jr. is Director of Library Services at Johnson \& Wales University and Instructor at the University of North Carolina at Greensboro.
This description of a pilot project where a library intern served as an informationist to teaching faculty is an interesting example of targeted outreach. It is also a reminder that librarians need to get out of the building to engage with faculty. This trial is an example of the expanding role of academic librarians.—Editor

$\mathrm{n}$ the early days of online bibliographic research, academic librarians served as search intermediaries, connecting users to expensive and difficult to access databases. Recently, search engines, which have been ubiquitous since the 1990s, have almost entirely displaced that role. ${ }^{1}$ However, there may be a need to reinstate a function that has defined librarianship. This need is not driven by simple economics as it was in the past, but by something closer to what J. Michael Holman reminded an audience of medical librarians in 2010. Holman quoted Herbert A. Simon as writing, "Today, the improvement of organizations and the information systems in them is not a matter of making more information available, but of conserving ... human attention so that it can focus on the information that is most important and most relevant."2 The scarce resource in many colleges and universities is the time and attention of the faculty, and the recognition of this fact is driving advocacy by many sources of new roles for librarians including the movement toward embedded librarianship, institutional repositories, and data managers. ${ }^{3}$

Holman called for an increase in the "informationist" role, which can be defined as a librarian who searches the information resources and provides context for it through a strong consulting relationship with information consumers. In small college libraries, one of the primary consumer groups is the faculty. Yes, faculty can find information quickly but it takes time and attention to put that information into a usable context. A pilot project conducted at Johnson and Wales University (JWU) in Charlotte, North Carolina, will illustrate both the need for this role and how it might work in practice.

\section{THE SETTING}

JWU opened in Providence, Rhode Island, in 1914 as a business college for women. Beginning in the 1980s and continuing through 2004, the university has expanded to include locations outside of Rhode Island, offering programs primarily in business, hospitality, and culinary arts. Current locations include Denver, Colorado, North Miami, Florida, and Charlotte, North Carolina, where this initiative took place. 


\section{FOR YOUR ENRICHMENT}

In 2004, JWU opened its Charlotte campus with approximately 1,000 students and has grown to enroll approximately 2,500 students as of April 2011. The move to Charlotte represented over time a significant financial and human resource investment. The academic leadership in Charlotte, in concert with the institutional strategic plan, placed increasing emphasis on academic rigor and deepening the student experience. The composition of the student body changed through increased selectivity, and the composition of the faculty shifted from primarily industry practitioners to a mix of academically credentialed and professionally qualified faculty.

As the university strategic plan (internally referred to as Focus 2011) progressed, the university continued to institute changes as it moved away from offering associates degrees in hospitality and business (now exclusively baccalaureate programs). Also, the university placed a greater emphasis on an evolving faculty development program that included in-service programs that incorporated teaching with technology, active learning, and the scholarship of teaching and learning. The director of Library Services under the direction of associate dean of Academic Affairs helped lead the organization with these efforts from 2008 through the present. The director's role included assistance in planning and facilitating sessions as well as recruiting appropriate outside speakers. Other librarians also played key roles in programming associated with faculty development workshops. Most in-services and workshops included a mix of internal and external talent and led to heavy faculty participation and significant presentations at the annual, regional Lilly College and University Teaching Conference.

It is within this context that the Charlotte campus library, already a host to prior interns from the University of North Carolina at Greensboro's MLIS program, was able to implement a special initiative with the arrival of a new intern. The concept was to focus greater attention on assisting faculty especially in areas related to acquiring new credentials and fostering more research in their areas of specialization and in pedagogy. The initiative was started on January 4 and concluded on May 1, 2011. During that time, 12 research reports were completed for 8 different professors. A total of 189 hours was spent on this initiative by the library intern.

\section{THE NEW RESEARCH SERVICE}

In advance of the spring semester, the director of library services e-mailed faculty that the library would be providing the services of a professional researcher during spring 2011 as part of a pilot project. The director also talked about the new service with members of the university's library committee, which consists of representatives from each of the different programs of the university. The library intern began work in January by meeting individual members of the College of Business in their offices. Accompanied by the liaison librarians for the Culinary Arts and Hospitality programs, the library intern introduced the service being provided at the regular departmental faculty meetings. The intent was to present the faculty with an image of the service connected to a particular person, the library intern. As such, attendance at the in-service sessions also promoted the new service.

Professors contacted the library intern by e-mail requesting help. Several attached their partially completed writings or an explanation of their current research project. A return e-mail was sent within 12 hours acknowledging the project and suggesting possible dates and times to meet within the next couple of days. Faculty members were able to schedule appointments at their convenience as the library intern worked a flexible schedule. Before the initial meeting, the library intern researched the professor's educational background, the courses they normally taught and were teaching during the current semester, and some initial research on the topic to be discussed.

\section{Consulting with Professors}

The library intern met one-on-one with the professor at a coffee shop on the JWU campus, but outside of the library. The idea was to bring the service to them and also provide a comfortable place where they wouldn't be distracted by colleagues or students. With a laptop and Wi-Fi connection, the services of the library were easily accessible during the meeting. The initial consultation focused on a reference interview developed by the library intern. Although the reference interview was adapted for each meeting, several basic questions follow:

- What's the topic of your research?

- How do you plan to use this information?

- How can I help you?

- Are there sources that you regularly use or that you would recommend? Databases? Search terms?

- What format do you want the information in? (Suggested an annotated bibliography)

- When do you need this information? Would you like to schedule a follow-up meeting? (Suggested 2 weeks out from the current date.)

One important lesson that was learned early on was not to assume any certain level of research experience. Each professor and each project was different. At the outset of each consultation, the groundwork was established for them to ask any question about anything with regards to their project. Some professors needed help with unfamiliar citation styles; others with understanding how to evaluate a source while others had their doctoral degree and had already published books or articles and were looking to update their research. Not everyone was familiar with using databases or other related technology. Others were offered assistance in preparing professional presentations. The intent was to help them in whatever way they needed to further their research.

\section{Conducting Research}

As each project was different, the research methods varied. Research methods included website searching, researching 
proprietary databases, using WorldCat and other library catalogs, and conducting primary research in the RobinsonSpangler Carolina Room of the Charlotte Mecklenburg Library. Materials from other libraries were retrieved through interlibrary loan.

The end result was always a report. It included a cover page, table of contents, research summary, and search log. The search log was actually a diary of what sources were consulted, search terms used, citations for relevant materials, and a cited abstract if one was available. The idea being that the professor would be able to go into further depth on their subject and be able to retrace the research steps with the information provided. The report also was e-mailed either before the follow-up meeting or immediately after because it included links to relevant sites. A hard copy was furnished during the consultation and reviewed with the professor.

Instruction on current awareness techniques was provided so that they would be able to keep up-to-date with their research after the initiative. Professors were asked if they wanted any additional information beyond what was provided in the report and encouraged to contact the library intern if they had any questions or needed any further assistance. E-mails were periodically sent by the library intern to keep in contact with the professor regarding their project. If additional relevant resources were found during a different search, the information was highlighted and forwarded to the professor.

\section{ASSESSING THE INITIATIVE}

While the success of the initiative was obvious as the number of requests for assistance quickly exceeded initial projections, a simple survey instrument was designed to help document results.

1. How well did the information provided meet your needs? (100 percent responded "Excellent.")

2. Did the research assistance provided help you move forward with your project? (100 percent rated the assistance at the highest level of "Very Helpful.")

3. Was the information provided in a timely manner? (16.7 percent indicated "When Promised" and 83.3 percent indicated "In Advance.")
4. How valuable was the service that you received? (100 percent rated the service as "High," the highest category.)

\section{Benefiting the University}

Not only did the faculty research initiative benefit faculty members but also it contributed to the goals of the university's strategic plan in further developing faculty and advancing teaching and learning on the Charlotte campus. Research information provided by the library intern was used in shaping course instruction and student projects. The library intern was able to provide input to the library staff in determining the pros and cons of various databases and identifying those most helpful for faculty research. Through contact with professors, the library intern recommended print resources for the library to add to the collection. In summary, the faculty became much more aware of the excellent resources and services available through their campus library.

\section{CONCLUSION}

The librarian's reference role is constantly evolving, and one direction may be toward that of informationist. The small pilot project described here was a successful trial of the application of this role in a small university library. Other trials may help describe this role more fully and make it a widely accepted part of what librarians accomplish in their work.

\section{References}

1. Karen Markey, "Twenty-five Years of End-user Searching, Part 1: Research Findings," JASIST 58, no. 8 (2007): 1071-81.

2. J. Michael Holman, "Eyes on the Prize: Reflections on the Impact of the Evolving Digital Ecology on the Librarian as Expert Intermediary and Knowledge Coach, 1969-2009," Journal of the Medical Library Association 98, no. 1 (2010): 49-56.

3. Association of College and Research Libraries, Value of Academic Libraries: A Comprehensive Research Review and Report (Chicago: Association of College and Research Libraries, 2010), www .ala.org/ala/mgrps/divs/acrl/issues/value/val_report.pdf (accessed Sept. 20,2011); Jake Carlson and Ruth Kneal, "Embedded Librarianship in the Research Context: Navigating New Waters," College E Research Libraries News 72, no. 3 (2011): 167-70; Mary M. Case, "Partners in Knowledge Creation: An Expanded Role for Research Libraries in the Digital Future," Journal of Library Administration 48, no. 2 (2008): 141-56. 